\title{
The Driving Lesson as a Socio- Technical Situation. A Case Study on the Interaction between Learner Driver, Driving Instructor, and the Motor Car
}

\author{
Alexander Schmidl \\ University of Erlangen-Nürnberg, Germany
}

DOI: http://dx.doi.org/10.18778/1733-8077.17.2.01

\section{Keywords:}

Microsociology;

Interactionist

Theory; Post-

Phenomenological

Sociology; Workplace

Studies; Videography

\begin{abstract}
A micro-sociological examination of the driving lesson raises the following question: How is the interaction between learner driver and driving instructor structured in this technical setting, and what meaning can be ascribed in this threefold constellation to the vehicle with its various technical elements? This case study examines the orientation patterns which exist between the learner driver, the driving instructor, and the car, which together constitute a socio-technical triangle, and what actions the learner driver needs to learn to enable them to drive the car safely. The theoretical background to the study is provided by interactionist theories, which have been broadened to include a greater sensitivity for the body and technology, and a sociological reading of postphenomenology. Using a method based on this theoretical background and informed by workplace studies, this study observed and made audiovisual recordings of driving lessons. This approach made it possible to undertake a detailed analysis of the situations, reveal how the human body interacts with technology, and how a person's attention responds to technical information. In these situations, the driving instructor takes on the role of the translator by mediating between various situational definitions-one's own, that of the inexperienced learner driver, other motorists, and the driver assistance systems in the car. The driving instructor represents the driving school as an institution that is responsible for creating an intersubjectively arranged understanding of how to deal with technology and socio-technical situations.
\end{abstract}

Alexander Schmidl is a postdoctoral assistant at the University of Erlangen-Nürnberg. He studied sociology at the University of Salzburg and completed his doctorate with a thesis on Online-Role-Playing-Games and the order of the senses in these provinces of meaning. His research interests include microsociology, phenomenological so- ciology, qualitative methods of social research, science \& technology studies, as well as the sociology of the body. Currently, he is working on the concept of "Post-Phenomenological Sociology."

email address: alexander.schmidl@fau.de 


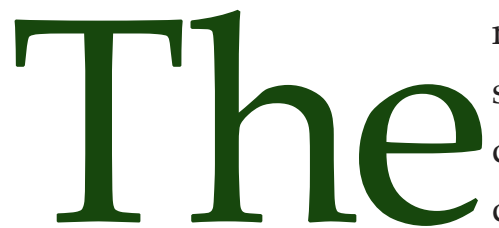

motor car embodies several aspects of modernity: mobility, individuality, freedom, and social prestige. It is a key aspect of people's everyday lives, especially for certain social groups such as young adults, the employed, or people living in the countryside. Obtaining a driving license, therefore, constitutes an important moment in people's socialization. It is the starting point for people's independent spatial mobility and opens the door to greater opportunities for social participation. In establishing a social order for road traffic and ensuring the safety of all road users, there is a public interest in making sure that learner drivers clearly and demonstrably learn how to operate a vehicle correctly. Since the beginning of driver training in the early $20^{\text {th }}$ century, motoring has become significantly more complex with regard to both automotive technology and the Highway Code. Learning to drive now takes several weeks, consists of a theoretical, as well as a practical examination, and costs the equivalent of a month's wages for people early on in their working lives. The driving school as a whole is of micro-sociological interest because of the multiplicity of situations that arise that make it necessary to reconcile the needs of people with different roles and expectations in a limited time and limited space. One of the most significant configurations in this context is the driving lesson. Whilst driving simulators are now available, the main focus of driver training is on gaining driving experience under realistic conditions. This brings together experienced driving instructors and inexperienced learner drivers. The car, thanks to various new technologies and driver assistance systems, is no longer simply a machine that needs to be operated. It gathers information that is intended to help the driver in their decision-making. Learner drivers and driving instructors must therefore not only be attuned to each other, but each must also be attuned to the car and its technical information. This triangular relation is the main focus of interest in this study. More specifically, this study examines the relationship between learner driver, driving instructor, and the car during a driving lesson, or phrased differently, it deals with interactive processes during a driving lesson. It is necessary to examine the relations between the three actors, as well as how these processes unfold because the situation in which they exist is never static. Instead, it is in a state of constant flux thanks to the movement of the car and the other road users. This study, therefore, seeks to document these processes and to show how a learner driver draws on them to develop the driving skills they need.

There have been several sociological studies about driving, but, first and foremost, with a focus on social norms in traffic and safety issues (e.g., Lupton 2002, Nazif-Munoz 2013). In contrast, this study's viewpoint is more in the tradition of researching movement and interaction in public spaces (like outlined by Conley 2012), faced with similar challenges in collecting data like Laurier (2008) and De Stefani and Gazin (2014).

This article is structured as follows: First, it draws on theories of social interaction and postphenomenology to establish the theoretical frame within which the analyses of the actors' interactions take place with each other and with technology. The second step builds on the first, setting out the research methodology and providing a description of the approach used here. The empirical basis for the study consists of video recordings of driving lessons. The material, lasting several hours, makes it possible to reconstruct individual processes in detail. Third, the 
results section then clearly shows how the relations between the participants change depending on the situation on the road and what the role of driver assistance systems is. The conclusion discusses how driving competence is acquired and how to understand the role of the driving school as an institution.

\section{Theoretical Frame}

Of particular importance of all interactionist theories are the theoretical approaches put forward by Garfinkel (2002) and Goffman (1986) because they focus on the social situation and interactions themselves. The driving lesson is a classic face-to-face situation in which the interaction partners are facing-or rather sitting next to-each other. Initially, they do not know each other, but they must quickly become attuned to each other and coordinate their actions. This is aided by them adopting the readymade roles of teacher and student, but these, too, are in a state of constant change depending on the situation. In this context, Goffman's (1983) interaction order serves as the sensitizing concept with respect to their interaction. Goffman's frame analysis and Garfinkel's ethnomethodology serve as the basis for analyzing the situation. The focus here is on how the interactional partners arrive at a common definition of a situation, or how they meaningfully interpret the events going on in the road traffic around them and agree on what to do. These theories are broadened here to give greater consideration to the body. This is because coming to a consensus with each other and acting in consideration of the other road users is not just about speech acts but also physical gestures and eye movements, so there is a high level of physical communication. Viewed phenomenologically, each consciousness experiences its situation which it relates to physically (Hitzler 1999:294). The socio-phenomenological question is then how it is still possible to bring these perspectives together as a common view of the world.

The question of physicality and the issue of finding a common perspective also play a significant role for the third actor in this constellation, namely, the car. Don Ihde (1990; 2009; 2012), in his postphenomenology, developed an approach for analyzing the relation between the physical subject and the machine. ${ }^{1}$ Drawing on a phenomenological and pragmatistical foundation, he examines the role of technology in the relation between human beings and the world and posits a theory that can be used to categorize and understand the various types of technology based on how they are used. Technology can be used to enhance the human body ("embodiment relation") or to increase the transparency of a world which is inaccessible to human experience ("hermeneutic relation"). Using technology can also consume a person's attention to the degree that the world behind it disappears ("alterity relation"), or the technology continues to function indiscernibly in the background ("background relation") (Ihde 1990). Dividing up the technology in this way is also helpful for this study as it reminds us that we cannot speak of a car as though it were a single piece of technology, when in reality it is a combination of various piloting and assistance systems. In addition, this theory also includes the concept of the "multistability" of technologies (Ihde 1990:70; 2012), an instrument that not only analyzes the variety of

\footnotetext{
${ }^{1}$ This approach tries to overcome a number of the limitations in phenomenology, which explains the use of the prefix post. It primarily seeks to give greater consideration to technology in relation to how people make sense of the world and position themselves in it. One of the best-known examples is Ihde's dispute with Husserl, who had described Galileo Galilei as a brilliant mind. Ihde (1990; 2011) countered by saying that it was primarily Galileo's ability to make lenses and place them correctly into telescopes that had allowed him to make his discoveries about the cosmos.
} 
technologies but also analyzes the significance ascribed to them based on their use in socio-technical situations.

The theoretical framework upon which this article rests, therefore, consists of interactionist theories and a theoretical approach rooted in the philosophy of technology. But, if this article seeks to analyze the relations between learner drivers, driving instructors, and the various technologies installed in cars, it must also address the problem of how to combine these theoretical approaches. It, therefore, adapts the interactionist theories to allow for greater sensitivity towards the body and technology, and it gives the philosophy of technology a sociological twist by broadening its focus from the individual person to the social situation. This study modifies interaction theory into an approach that posits an empirical question, namely, how the technology intervenes in situations and how it is used by the actors involved. This means that the study is not limited to the effects and the interaction between the three actors, but the meaningful interpretation of action and the consolidation of interaction patterns in the driving culture as a whole.

\section{Research Methodology}

Interactionist theories and postphenomenology share an interest in concrete situations in people's life-worlds and how these run their course. Interaction theories have succeeded in demonstrating that there is no such thing as action in itself, but only action that takes place to achieve something definitive. In line with phenomenology, where is argued that there is no consciousness per se, but only a consciousness of something, not an experience in itself, but only of something, postphenomenology stresses that there is no such thing as "technolo- gy-in-itself," but only a "technology-in-order-to" (Verbeek 2005:117). Of critical importance here are the situational conditions and how technology is actually used. As mentioned above, the defining characteristic of the driving lesson is that the situation is in a state of constant change as the people and vehicle move about. The methodological challenge here is, therefore, to give due consideration to all of these dynamic aspects. Workplace studies, which have their roots in ethnomethodology, have devoted considerable attention to both the technology and the processual nature of the action. Their basic premise is that complex environments contain an inestimable number of events and problems that require a spontaneous reaction (Knoblauch 2000:163). Situations of such complexity are mostly found in high-tech workplaces, hence the name of this branch of research, for which Lucy Suchman (see her renowned study Plans and Situated Actions [1985]) and Charles Goodwin (i.a., Goodwin and Goodwin 1996) are largely responsible. Garfinkel (1986), towards the end of his research, devoted himself to work-related processes, focusing on the physicality of actions. His work follows on from that of Merleau-Ponty and speaks of embodied experience, embodied practices, and embodied actions (Garfinkel 2002). What is decisive here is that these actions as understood by ethnomethodology are accountable, in contrast to consciousness processes formulated by Schütz, which otherwise play a central role in social phenomenology. Kissmann (2014:7; 2019:31f), drawing on Merleau-Ponty's concept of intercorporeity, states that movements and gestures are also meaningful and can, therefore, also be construed and understood both in the everyday world and in the world of sociological interpretation.

To document the interactions taking place in these highly technical contexts, workplace studies use 
video cameras to record the events and subject them to detailed analysis. The methodology underlying the use of video cameras was most recently advanced and improved by Knoblauch und Tuma (e.g., 2020), who used technology in ethnographic settings and not only in workplace contexts. Video material permits the evaluation of language-based and physical interactions in detail, repeatedly, and without time pressure or a sense of urgency. However, it should be borne in mind that these data only depict a snapshot of reality. But, the recorded section can be precisely fixed in time and subjected to hermeneutic analysis. Against this ethnomethodological background and with a hermeneutic intensity, the principle concept here is that of sequentiality. This means that the data are analyzed in the order in which they happen, second by second, enabling the gradual examination of the composition of action and the actors' reactions to it. In contrast to interview transcripts, in which the text represents the only available data and that can be reproduced in a linear form, audio-visual material must be analyzed on several levels due to its density. This gives rise to something akin to the different levels in musical scores wherefore roughly the differentiation between language and visible actions is made, and which can be subdivided further depending on the field of inquiry.

\section{The Study}

This study is a piece of ethnographic research conducted in two driving schools in German cities between September 2016 and March 2019. The data consist of participant observation of driving lessons, video recordings of these lessons, analyses of the technology in the vehicles, the underlying legal and economic frameworks, and interviews with a range of actors in situ.
The first three observations were useful to get an acute sense of the relevant processes. However, it became clear that the complexity of these situations demanded some adaptation in the methodical approach to getting a closer look at the interaction on the micro-level. Hence, driving lessons were recorded using a camera that was positioned in the middle of the back seat and had a view of the learner driver, the driving instructor, the dashboard, and the traffic situation in front of the car. ${ }^{2}$

Figure 1. Still Image from the Video Recording (defamiliarized)

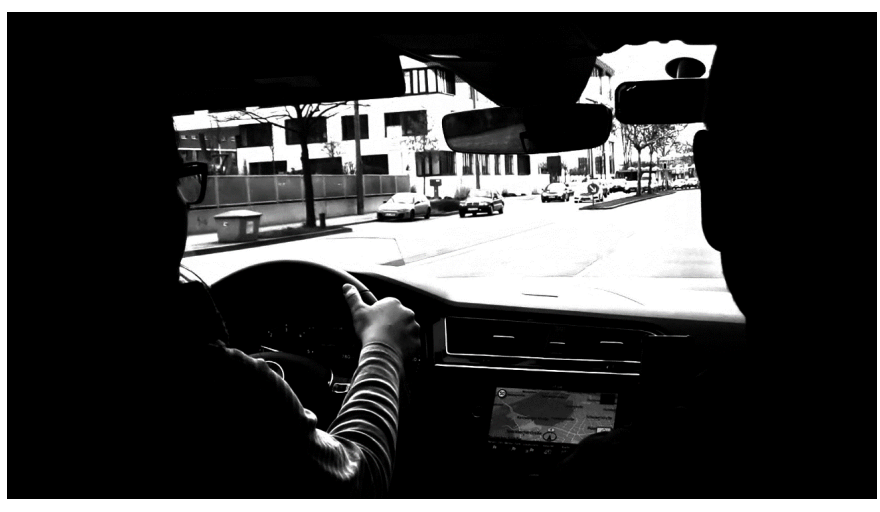

Source: Self-elaboration.

For this inquiry, the data are provisionally restricted to these observed, as well as recorded driving lessons and which are mandatory for people learning to drive motor vehicles weighing up to 3.5 tons.

\footnotetext{
${ }^{2}$ Data collection required several criteria to be balanced against each other. First, the degree of intervention in the situation had to be considered; second, the driving instructor's periodic safety warnings had to be taken into consideration; and third, the quality of the data had to be ensured. Ultimately, the back seat transpired to be the best recording position, although the camera had to be tipped to the side by the researcher whenever the driving instructor considered the view to the rear to be a relevant safety issue.
} 
Whilst initial contact was with the owners of the driving schools, the key figures in the studies were the driving instructors with whom the surveys were arranged and who were responsible for establishing a connection with the learner drivers. Regarding the sampling, the aim was to observe typical situations during the driving lessons. Aware of this, the driving instructors proposed to join lessons like driving in city traffic, on a country road and highway, exercising parking, or filtering in a flow of traffic. After the first analyses and in the further course, the attention has been centered on the driver assistance systems. Similar to the idea of theoretical sampling in grounded theory, driving lessons in which these devices were of significance were chosen deliberately. A secondary sampling criterion was the observation of learner drivers with different levels of experience, whereas other criteria like gender or age could not have been considered in the sampling but have been taken into account in the analyses. After eight lessons, four of them with focus on parking assistance systems, and 17 recorded parking maneuvers, a saturation has been achieved and the data collection has been concluded.

Table 1. Overview of the Observed and Recorded Driving Lessons

\begin{tabular}{|c|c|c|c|c|c|}
\hline Lesson & Date & Subject & Learner & Instructor & Method \\
\hline 1 & 09/2016 & City Traffic & $\begin{array}{l}\text { AA (semi-experienced, } \\
\text { male, } 18-25 \text { years) }\end{array}$ & $\begin{array}{l}\text { B (male, } 30-40 \\
\text { years) }\end{array}$ & Participant Observation \\
\hline 2 & 09/2016 & Country Road & $\begin{array}{l}\text { BB (inexperienced, } \\
\text { female, } 18-25 \text { years) }\end{array}$ & $\begin{array}{l}\text { B (male, } 30-40 \\
\text { years) }\end{array}$ & Participant Observation \\
\hline 3 & $10 / 2016$ & $\begin{array}{l}\text { Motorcycle } \\
\text { Driving Lesson }\end{array}$ & $\begin{array}{l}\text { CC (semi-experienced, } \\
\text { female, 18-25) }\end{array}$ & $\begin{array}{l}\text { B (male, } 30-40 \\
\text { years) }\end{array}$ & Participant Observation \\
\hline 4 & \multirow{2}{*}{$10 / 2018$} & Reverse Parking & \multirow{2}{*}{$\begin{array}{l}\text { AR (semi-experienced, } \\
\text { female, } 17 \text { years) }\end{array}$} & \multirow{2}{*}{$\begin{array}{l}\mathrm{S} \text { (male, } 20-30 \\
\text { years) }\end{array}$} & \multirow{2}{*}{$\begin{array}{l}\text { Participant Observation and Video } \\
\text { Recording (37:14, 11:08, 21:34 min.) }\end{array}$} \\
\hline 5 & & Reverse Parking & & & \\
\hline 6 & \multirow{2}{*}{$11 / 2018$} & Highway & \multirow{2}{*}{$\begin{array}{l}\text { AR (semi-experienced, } \\
\text { female, } 17 \text { years) }\end{array}$} & \multirow{2}{*}{$\begin{array}{l}S \text { (male, } 20-30 \\
\text { years) }\end{array}$} & \multirow{2}{*}{$\begin{array}{l}\text { Participant Observation and Video } \\
\text { Recording (37:14, 25:18 min., } \\
\text { interrupted due to technical problems } \\
\text { during the second lesson) }\end{array}$} \\
\hline 7 & & $\begin{array}{l}\text { Night-Time } \\
\text { Driving Lesson }\end{array}$ & & & \\
\hline 8 & \multirow{2}{*}{$02 / 2019$} & City Traffic & \multirow{2}{*}{$\begin{array}{l}\text { MS (inexperienced, } \\
\text { female, } 18-25 \text { years) }\end{array}$} & \multirow{2}{*}{$\begin{array}{l}S \text { (male, } 20-30 \\
\text { years) }\end{array}$} & \multirow{2}{*}{$\begin{array}{c}\text { Participant Observation and Video } \\
\text { Recording }(37: 14,19: 59,37: 14,11: 39 \\
\text { min. })\end{array}$} \\
\hline 9 & & Reverse Parking & & & \\
\hline 10 & \multirow{2}{*}{ 03/2019 } & Reverse Parking & \multirow{2}{*}{$\begin{array}{c}\text { RS (experienced, } \\
\text { female, } 18-25 \text { years, } \\
\text { deaf) }\end{array}$} & \multirow{2}{*}{$\begin{array}{l}\text { F (male, } 50-60 \\
\text { years) }\end{array}$} & \multirow{2}{*}{$\begin{array}{l}\text { Participant Observation and Video } \\
\text { Recording }(37: 14,10: 29,28: 51 \text { min.) }\end{array}$} \\
\hline 11 & & Exam Preparation & & & \\
\hline
\end{tabular}

Source: Self-elaboration. 
The main research interest is the interaction between the learner driver, the driving instructor, and the motor car. During the circular process of data collection and data evaluation, it becomes apparent that situations where assistance systems were used (or intervene automatically) are of vital importance. For the analyses, typical trouble free-situations and, in contrast, some key events were chosen. The latter are especially complicated situations that took place beyond practiced routines and required several acts of mutual consultation before they could be understood and mastered.

To reduce the density of the data, the transcription of the material was categorized as follows:

Table 2. Tracks in the Multilayered Transcript

\begin{tabular}{|c|c|c|}
\hline & Visual Events & Acoustic Events \\
\hline $1^{\text {st }}$ track & $\begin{array}{c}\text { Eye movement learner } \\
\text { driver }\end{array}$ & $\begin{array}{c}\text { Speech learner } \\
\text { driver }\end{array}$ \\
\hline $2^{\text {nd }}$ track & $\begin{array}{c}\text { Body movement learner } \\
\text { driver }\end{array}$ & $\begin{array}{c}\text { Speech driving } \\
\text { instructor }\end{array}$ \\
\hline $3^{\text {rd }}$ track & $\begin{array}{c}\text { Eye movement driving } \\
\text { instructor }\end{array}$ & $\begin{array}{c}\text { Driver assistance } \\
\text { system }\end{array}$ \\
\hline $4^{\text {th }}$ track & $\begin{array}{c}\text { Body movement driving } \\
\text { instructor }\end{array}$ & Engine noise \\
\hline $5^{\text {th }}$ track & $\begin{array}{c}\text { Steering wheel position } \\
6^{\text {th }} \text { track }\end{array}$ & Position of the vehicle \\
\hline $7^{\text {th }}$ track & $\begin{array}{c}\text { Readings on instruments } \\
\text { of the central console }\end{array}$ & \\
\hline
\end{tabular}

Source: Self-elaboration.

The analysis is based on hermeneutic video analysis as formulated by Kissmann (2014). By dividing up the various acoustic and visual events, this study is constructed in line with what Kissmann (2014:8)-in her critical examination of Goffman's approachdemands, namely, a separate examination of visual behavior, as well as speech. This explains why each track is subjected to independent sequential second-by-second analysis. After this has taken place, these separate parts must be recombined using a systematic approach to connect the different levels (Kissmann 2014:128f). This reflects the key characteristic of Kissmann's hermeneutic video analysis stating that the situational events are subdivided into their constituent parts before gradually being reconstructed to identify connections between them over time.

\section{The Triangular Relationship between Learner Driver, Driving Instructor, and the Car}

\section{Learner Driver - Driving Instructor}

Most learner drivers have already watched someone else driving a car as passengers. This gives them some general knowledge about driving, but not about how the driver is required to use their body and attention to actually drive the car. Indeed, just getting a car rolling in their first driving lesson is a considerable challenge for most learner drivers. In contrast, the driving instructors have many years of experience driving cars, have developed numerous physical routines that make driving second nature to them, and have completed a year-long course as driving instructors. This knowledge is not only subconscious, the driving instructors are also able to make this knowledge explicit and communicate it to others. In addition, they are also occupying a role that enables them to define a situation and to intervene at critical moments, since it is they who are responsible for safety during the driving lesson. From a social perspective, there is an additional asymmetry between the learner drivers and the driving instructors because the latter are al- 
most always older than them and mostly men. Driving instructors communicate their directions and instructions mainly through speech. Sometimes they use more metaphorical language, such as when they describe the clutch pedal as a kind of sponge that the learner driver should squeeze out gently. And, at times, they give instructions incidentally through subtle gestures. The communicative contribution of the learner driver is, in contrast, relatively minimal, or they express their answers by physically implementing the driving instructor's instructions by accelerating, braking, or steering, which the driving instructor then reacts to in turn.

After the learner drivers have internalized the knowledge they need to drive a car, the routines they have adopted permit a second communicative level to be opened in parallel to the driving itself. The learner and the instructor then exchange thoughts about the music on the radio, the surroundings, school, and free-time activities. Their social relationship gradually becomes increasingly friendly. But, this can revert at any time, as shown by the driving instructor's ability to suspend friendly relations in complex road traffic situations, to reimpose their definitional authority, and demand that the learner driver take the necessary actions to ensure safety on the road. In particularly harmonious pairings, these two behavioral contexts can overlap. Situations then arise during the lesson in which the driving instructor uses their hand to indicate whether the learner driver should go faster or slow down, without interrupting conversations unrelated to driving. However, this does not constitute deep layering with multiple keyings (Goffman 1986:156f), ${ }^{3}$ but the overlapping of several

${ }^{3}$ Goffman (1986) describes several cases in which an event is subject to keying, when this transformative event is, in turn, transformed itself, and when even the rekeying can be transformed once again. frames (Schmidl 2017) in which the participants are in a position to sustain several situations and roles simultaneously.

\section{Learner Driver - Car}

In established theories, such as philosophical anthropology, the car in the driver-car relation can be viewed as an extension of the body which it uses to increase its operational range. ${ }^{4}$ Individual components in the car can also be seen as extending or strengthening the body. For example, the body uses the brake pedal to transfer its muscle power through a network of rods to bring the car to a halt. This effect is enhanced still further by the car's servo-assisted braking system.

But, technology does not only assist the driver in the practical business of operating the car. Technology also helps the driver register what is going on around them. Parking maneuvers are assisted by rearview cameras, optical warnings on a screen, and distance sensors. One of the scenes I recorded reveals how the driver's sense of position is enhanced, but also made much more challenging.

When reversing into a parking space, the learner driver first looks around and checks the road traffic situation. During the parking maneuver, she looks back and forth between the near side wing mirror and the rearview camera screen 16 times. In addition, the signal emitted by the distance sensor is beeping constantly and changing in frequency as she approaches the object behind the car. [Memo 21b]

\footnotetext{
${ }^{4}$ Philosophical anthropology describes human beings primarily as beings of shortcomings and deficiencies (Mängelwesen) who must compensate for their deficient abilities through the use of technology (Gehlen 1957). The concept of "extension" was applied later by McLuhan (1994) for media as "Extensions of Man."
} 
The learner driver does not look directly through the rear windscreen. Instead, she views the situation indirectly through the wing mirror and the image provided by the camera and uses the beeping signal emitted by the distance sensor to get a sense of her position. To be able to unify all of this sensory input, she must first interpret an abstract signal such as the beeping signal from the distance sensor. Here, we are dealing with a hermeneutic relation as described by Ihde (1990:80-97) because whilst the technology enhances the driver's view of the traffic situation, the driver must first interpret this information. This means, in this case, that the driver has to translate an audible sound frequency into a spatial distance in their mind.

More recent technical systems are even capable of using the data about vehicle speed and distances to other objects autonomously. In an emergency, the vehicle can activate an emergency brake assistant to prevent an accident. This kind of autonomy means that the vehicle becomes a "quasi other," a participant in the situation that must also be taken seriously, as described by Ihde (1990:108).

Overall, it is clear that the technical systems in a car are not just tools. They intrude into the driver's operation of the vehicle, and might well intervene autonomously to a greater degree in the future. But, this trend towards autonomous vehicles brings with it a number of ethical questions, depending on the degree to which the responsibility for decision-making is transferred to technical systems. ${ }^{5}$

\footnotetext{
${ }^{5}$ The automotive industry differentiates between five different types of autonomous driving. The driver assistance systems mentioned here are level 1 systems. Subsequently, further systems such as automatic parking assistants were introduced (2), along with autonomous driving for long periods of a journey (3), fully autonomous driving (4), and complete automation of traffic (5).
}

\section{Driving Instructor - Car}

Interaction between the driving instructor and the car is minimal. Besides a few aspects of comfort and convenience such as adjusting the temperature, air conditioning, and radio, all of which are accessible to the passenger, the car is constructed so that technology is primarily accessible to the driver. The driving instructor's main focus is on the actions of the learner driver whom they are observing along with the road traffic situation. In an emergency, they are also able to apply the brake and prevent dangerous situations because the cars have been customized for driving instructors to give them a second set of pedals. Otherwise, the driving instructor's role is to mediate between the car and the learner driver.

\section{Learner Driver - Driving Instructor - Car}

At the beginning of their training, it is in the best interests of the learner driver if the complexity of the situation is kept to a minimum. Practicing parking maneuvers in convenient parking spots or quiet side streets means they are not required to devote much attention to other traffic, but can concentrate on operating the vehicle and listening to the instructions issued by the driving instructor. Managing to cope with a simple situation also reduces the learner's fear of damaging the expensive car (which is, nevertheless, sufficiently well-insured). In real road traffic, however, the complexity of driving the car increases; learner drivers try to cope with this situation by driving slowly and dealing with changes in their situation, and making decisions about their actions one at a time.

It is the job of the driving instructor not to further intensify the situation, but to notice when the learner is unsure of themselves and to provide the necessary 
guidance and tips to solve the learner's subjective or situational problems. To do this, they must-to reference Goffman here-identify the different frames and place them in relation to each other. The driving instructors themselves have their definition of the situation and can, based on their experience, say with some certainty what course of action to take. But, they are initially unable to say how the learner driver is defining a situation because the learner is not in a position to explain what they are seeing and feeling. The driving instructor must, therefore, interpret the learner's eye and body movements to discover how the learner has defined the situation. If there is a difference between the driving instructor's definition of the situation and the learner's definition as interpreted by the instructor, then the instructor will issue instructions to the learner.

The car itself is a part of the situation to be defined. Learner and instructor alike both observe the position of the car and how it reacts during the drive. But, the car itself, equipped with modern assistance systems as it is, also contributes to defining the situation in some way (Schmidl 2017). Whilst it is not possible-at least not in a strict sense-to say that the technical systems contribute to defining the situation, they are capable of registering the road traffic situation and the actions of the learner driver. For instance, when changing lanes on the motorway, the driver assistance systems draw the driver's attention to other vehicles in the car's blind spot. They tell the driver when their vehicle is too close to another during parking maneuvers, or when a driver needs to perform an emergency braking procedure to avoid rear-ending the car in front. This kind of information, coupled with warning signals, helps a driver to operate their vehicle safely. But, they are also additional events that demand the attention of an already challenged learner driver. In a hermeneutic relation, the information is not self-evident and requires interpretation, meaning the driving instructor must act as a translator between the driver assistance systems and the learner driver. The complexity of a situation of this kind and the instructor's role is demonstrated by the following example.

In the first step, every single track is viewed individually.

1 As can be seen in the first row, for example, the learner driver looks at the display of the rearview camera two times, but then directs her full attention to the right-wing mirror.

2 She even moves her upper body and head to variegate the view in the mirror.

5, 6 As recorded in rows five and six, she neither changes the steering angle nor slows down.

6 This time, the car moves back and approaches an object behind it.

10 The reverse sensor detects this, and the assistance system starts to beep increasing the frequency of the beeping up to a continuous tone.

7 The red warning line appears on the display of the central console for the same reason.

3 The driving instructor looks at the right-wing mirror, as well, but then turns his view to the driver learner and monitors her orientation.

9 He starts to explain what the assistance system is showing,

4 and points to the display. 
Table 3.1. Simplified Representation of the Transcript of a Reverse Parking Maneuver

\begin{tabular}{|c|c|c|c|c|c|c|c|c|c|c|}
\hline & 00.01 .12 & 00.01 .13 & 00.01.14 & 00.01.15 & 00.01 .16 & 00.01 .17 & 00.01 .18 & 00.01.19 & 00.01 .20 & 00.01 .21 \\
\hline Eye movement learner driver & $\begin{array}{l}\text { right- } \\
\text { wing } \\
\text { mirror }\end{array}$ & display & \multicolumn{4}{|c|}{ right-wing mirror } & display & $\begin{array}{l}\text { right- } \\
\text { wing } \\
\text { mirror }\end{array}$ & \multicolumn{2}{|l|}{ forward } \\
\hline $\begin{array}{l}\text { Body movement learner } \\
\text { driver }\end{array}$ & & & & & & \multicolumn{2}{|c|}{ straightens up } & & & \\
\hline $\begin{array}{l}\text { Eye movement driving } \\
\text { instructor }\end{array}$ & & & & \multicolumn{5}{|c|}{ right-wing mirror } & $\begin{array}{l}\text { to the } \\
\text { learner }\end{array}$ & \\
\hline $\begin{array}{l}\text { Body movement driving } \\
\text { instructor }\end{array}$ & & & & & & \multicolumn{3}{|c|}{ bends forward } & & \\
\hline Steering wheel position & \multicolumn{10}{|l|}{ hard left } \\
\hline Position of the vehicle & \multicolumn{3}{|c|}{ beginning of the parking space } & \multicolumn{7}{|c|}{ moves back } \\
\hline $\begin{array}{l}\text { Readings on instruments of } \\
\text { the central console }\end{array}$ & \multicolumn{6}{|c|}{ a rearview camera with augmented reference lines } & \multicolumn{4}{|c|}{ a rearview camera with red warning lines } \\
\hline \multicolumn{11}{|l|}{ Speech learner driver } \\
\hline \multicolumn{11}{|l|}{ Speech driving instructor } \\
\hline Driver assistance system & & \multicolumn{4}{|c|}{ slow beeping } & \multicolumn{5}{|c|}{ fast beeping } \\
\hline Engine noise & \multicolumn{10}{|c|}{ gentle at a low rotation speed } \\
\hline
\end{tabular}

Source: Self-elaboration.

Table 3.2. Simplified Representation of the Transcript of a Reverse Parking Maneuver

\begin{tabular}{|c|c|c|c|c|c|c|c|c|c|}
\hline & 00.01 .22 & 00.01 .23 & 00.01 .24 & 00.01 .25 & 00.01 .26 & 00.01 .27 & 00.01 .28 & 00.01 .29 & 00.01 .30 \\
\hline Eye movement learner driver & \multicolumn{9}{|c|}{ right-wing mirror } \\
\hline $\begin{array}{l}\text { Body movement learner } \\
\text { driver }\end{array}$ & \multicolumn{5}{|c|}{ straightens up and bends forward } & \multicolumn{3}{|c|}{$\begin{array}{l}\text { points with the forefinger to the } \\
\text { right-wing mirror }\end{array}$} & \\
\hline $\begin{array}{l}\text { Eye movement driving } \\
\text { instructor }\end{array}$ & $\begin{array}{l}\text { to the } \\
\text { learner }\end{array}$ & & & & & & & & \\
\hline $\begin{array}{l}\text { Body movement driving } \\
\text { instructor }\end{array}$ & & & \multicolumn{2}{|c|}{$\begin{array}{l}\text { points to the } \\
\text { display }\end{array}$} & & & & & \\
\hline Steering wheel position & \multicolumn{9}{|l|}{ hard left } \\
\hline Position of the vehicle & \multicolumn{9}{|c|}{ moves back } \\
\hline $\begin{array}{l}\text { Readings on instruments of } \\
\text { the central console }\end{array}$ & \multicolumn{9}{|c|}{ a rearview camera with red warning lines } \\
\hline Speech learner driver & & & & yes & & & & yes & \\
\hline Speech driving instructor & & Well, it is qu & te sensitive. & & But, yes. & & $\begin{array}{l}\text { The back of } \\
\text { the car }\end{array}$ & $\begin{array}{l}\text { - can you } \\
\text { see it? - }\end{array}$ & $\begin{array}{l}\text { has touched } \\
\text { the curb. }\end{array}$ \\
\hline Driver assistance system & \multicolumn{9}{|c|}{ continuous tone } \\
\hline Engine noise & \multicolumn{9}{|c|}{ gentle at a low rotation speed } \\
\hline
\end{tabular}

Source: Self-elaboration. 
In the second step, the different tracks of the event can be put in relation to each other. The first important point in time is the moment when the beeping of the assistance system picks up the pace (00.01.17), and the learner driver looks at the screen, which shows her the view provided by the rearview camera (00.01.18). After that, she relies on the right side wing mirror to establish her position. Even when the signal becomes a continuous tone (00.01.22), she still reverses a few more centimeters, but the driving instructor does not intervene. Instead, he provides an insight into his interpretation of the warning signal ("Well, it is quite sensitive. But, yes. The back of the car-can you see it?-has touched the curb."). He sees that the learner is directing her attention to the screen because of the beeping, and is forced into the role of translator for the technical system. He then confirms that there is, indeed, very little space behind the car, but that it is just the curb, and that there is no real danger despite the continuous warning signal. Whilst he tries to verify the situation by using the rearview camera (00.01.24), the learner driver is looking at the wing mirror.

To emphasize the crucial role of the driving instructor, another sequence can be used where he acts as a translator but in another sense.

Table 4. Simplified Representation of the Transcript of a Second Reverse Parking Maneuver in this Sequence

\begin{tabular}{|c|c|c|c|c|c|c|c|c|}
\hline & 00.34 .00 & 00.34 .01 & 00.34 .02 & 00.34 .03 & 00.34 .04 & 00.34 .05 & 00.34 .06 & 00.34 .07 \\
\hline Eye movement learner driver & \multicolumn{3}{|c|}{ rear window } & \multicolumn{5}{|l|}{ display } \\
\hline Body movement learner driver & \multicolumn{2}{|c|}{ head turns backwards } & \multicolumn{6}{|c|}{ head turns forward } \\
\hline Eye movement driving instructor & \multicolumn{8}{|c|}{ (not visible) } \\
\hline \multicolumn{9}{|l|}{ Body movement driving instructor } \\
\hline Steering wheel position & hard right & & & & & & & \\
\hline Position of the vehicle & $\begin{array}{l}\text { moves } \\
\text { back }\end{array}$ & \multicolumn{4}{|c|}{ moves fast back } & \multicolumn{2}{|c|}{ slows down } & stopped \\
\hline $\begin{array}{l}\text { Readings on instruments of the } \\
\text { central console }\end{array}$ & \multicolumn{8}{|c|}{ rearview camera } \\
\hline Speech learner driver & & & & & & & \multicolumn{2}{|c|}{ Was it too much? } \\
\hline Speech driving instructor & & & & & \multicolumn{3}{|c|}{ Sh---sh--sh-shsh } & uh-huh! \\
\hline Driver assistance system & & & & & & & & \\
\hline Engine noise & & & \multicolumn{3}{|l|}{ revving } & & & \\
\hline
\end{tabular}

Source: Self-elaboration.

Without writing out the single tracks and relating them, it can be outlined that the instructor's "Sh - - - sh - - sh - shsh" is the crucial point here. The driver learner moves fast backward in a sharp right steering angle and the car faces an unsafe turn. The assistance system remains quiet because, at the moment, there is no object nearby and it is not able to recognize such kind of danger. The driving instruc- 
tor is forced to intervene and there are multiple alternatives to do so, for example, by saying "slowly" or "stop!" or maybe even applying the brakes himself. Instead, he chooses to play the role of the assistance system and imitates its beeping, starting with a slow "Sh - - - sh - - sh" and speeds up as the car picks up the pace, "sh - shsh." In this case, he does not try to explain the assistance system that seemed to be too sensitive in the other situation, he rather takes its place as a warning agent.

Both scenarios show how the driving instructor teaches the learner driver how to coordinate one's attention, incorporate the assistance systems in doing so, or anticipate events of sudden danger. Subsequently, however, at the end of the driving lessons, they manage to coordinate the technical information and their eye movements sufficiently well for them both to arrive at a shared definition of the situation and agree on a course of action.

\section{Conclusions}

What the learner driver does as a matter of routine in their everyday driving career after they have earned their driving license must be learned through hard work at the start of their driver training. They must learn to operate their vehicle following the Highway Code, to employ their body correctly, and to focus their attention. The key to doing this is in the practice they get during their driving lessons and in the interaction between learner driver and driving instructor. Practical driver training mostly takes place on the road, something which gives rise to unforeseen situations. Despite this, driver training is highly formalized because it teaches the learner driver a series of typical actions for typical traffic situations based on planning and rules. Because traffic situations are so complex, it is also the case that the driver's attention might be divided between several different factors and that these can be interpreted in a number of different ways. The driving instructor plays a key role here because they have to weigh up the different stimuli and instruct the learner to concentrate on one particular event and react to it in a particular way. It is also becoming increasingly important for the learner to interpret the driver assistance systems correctly. This is because the car is no longer merely an object and an instrument, it actually provides additional information about the traffic situation and can sometimes even intervene in a situation itself. The driving instructors, therefore, occupy the role of translators because it is up to them to point out what information the learner should take into account and when (and when it might even be incorrect), and how the learner should integrate this information into their actions.

A learner driver's training can be considered a success when the driving instructor has succeeded in making their knowledge explicit and communicating it to the learner, who, in turn, incorporates it, internalizes it, and turns it into habitual knowledge. It is, therefore, important in this process for the learner and instructor to come to a common understanding of the skills and abilities-including technical ability-which are required to comprehend and interpret situations as they arise. Road safety is then little more than a consensus about what is happening and what to do about it. Consequently, the driving school is a social institution, the purpose of which is to ensure, in a multifaceted social and technical context such as road traffic, that this consensus exists based on shared knowledge and that it is clear to all road users what they can expect and what is expected of them.

In addition to these topics, it is also of theoretical and methodological interest for sociology how tech- 
nology can be conceptually incorporated into these processes. Because we are dealing with a number of different technologies that have to adapt to various situations, it is not necessary to view technology as an actor from the outset. So long as we are not only dealing with functionality-for which the concept of action can be broadened and the differences between human and non-human actors can be set aside-but also sense-making, other approaches besides actor-network theory lend themselves well to describing the interplay between the various actors. This study proposes using postphenomenology and its granular view of human-machine relations. ${ }^{6}$ Between the human body and the car braking mechanism that enhances the strength of the body, there is an embodiment relation. Whilst it is not possible for a third party to feel this relation and react to it, the warning signal emitted by the distance warning device, which results in a hermeneutic relation, is, however, audible to all and must frequently be interpreted in collaboration. Increasing automation in transport and communications is leading to an increase in autonomous technologies, which, as quasi-others, are creating alterity relations. In the future, what these advanced technolo-

${ }^{6}$ Other new approaches might also be included here, including posthumanism (Braidotti 2013) or, from the field of sociology, the theory developed by Knorr Cetina (1997) about a "sociality with objects" in a "postsocial" era.

\section{References}

Braidotti, Rosi. 2013. The Posthuman. Cambridge: Polity Press.

Conley, Jim. 2012. "A Sociology of Traffic: Driving, Cycling, Walking." Pp. 219-136 in Technologies of Mobility in the Americas, edited by P. Vannini. Oxford, Berlin: Peter Lang.

De Stefani, Elwys and Anne-Danièle Gazin. 2014. “Instructional Sequences in Driving Lessons: Mobile Participants and the gies are capable of registering and doing will present a challenge to the way human actors interact, as they might well find themselves having to cope with these "third parties" interacting with each other.

Henkel (2016:82f) identifies two polar opposite viewpoints in the discussion about what can be included in the social: only people belong to the social, or everything belongs to the social. However, this study calls for an approach that examines everyday activity and practice to identify the significance of individual technologies and what role can be ascribed to them depending on the situation. This proposal is based on the work of Lindemann (1999; 2009), who advocates undertaking empirical tests to establish how the social comes into being, what it is exactly that it includes, and where the boundaries of the social should, therefore, be drawn.

To render this empirical question of use to interaction theories, too, it is necessary to identify the exact points at which technology can be integrated and how. In addition, empirical social research can also for its part use technology, namely, by recording interactions with video cameras. Whilst this use of technology must be subject to further methodological thought, the recordings certainly make it possible to reconstruct the dynamic and situationally dependent relationship between actors and technology.

Temporal and Sequential Organization of Actions." Journal of Pragmatics 65:63-79.

Garfinkel, Harold, ed. 1986. Ethnomethodological Studies of Work. London: Routledge and Kegan Paul.

Garfinkel, Harold. 2002. Ethnomethodology's Program. Working Out Durkheim's Aphorism. Lanham, Boulder, New York, Toronto, Oxford: Rowman \& Littlefield Publishers. 
Gehlen, Arnold. 1957. Man in the Age of Technology. New York: Columbia University Press.

Goffman, Erving. 1983. “The Interaction Order. American Sociological Association, 1982 Presidential Address." American Sociological Review 48(1):1-17.

Goffman, Erving. 1986. Frame Analysis: An Essay on the Organization of Experience. Boston: Northeastern University Press.

Goodwin, Charles and Marjorie Harness Goodwin. 1996. "Seeing as a Situated Activity: Formulating Planes." Pp. 61-95 in Cognition and Communication at Work, edited by Y. Engeström and D. Middleton. Cambridge: Cambridge University Press.

Henkel, Anna. 2016. "Posthumanism, the Social and the Dynamics of Material Systems." Theory, Culture E Society 33(5):65-89.

Hitzler, Ronald. 1999. “Konsequenzen der Situationsdefinition. Auf dem Weg zu einer selbstreflexiven Wissenssoziologie [Consequences of the Definition of the Situation. On the Way to a Self-Reflective Sociology of Knowledge]." Pp. 289-308 in Hermeneutische Wissenssoziologie. Standpunkte zur Theorie der Interpretation [Hermeneutic Sociology of Knowledge. Viewpoints on the Theory of Interpretation], edited by R. Hitzler, J. Reichertz, and N. Schröer. Konstanz: UVK.

Ihde, Don. 1990. Technology and the Lifeworld. From Garden to Earth. Bloomington, IN: Indiana University Press.

Ihde, Don. 2009. Postphenomenology and Technoscience. The Peking University Lectures. SUNY series in the Philosophy of the Social Sciences. Albany, NY: State of University New York Press.

Ihde, Don. 2011. “Husserl's Galileo Needed a Telescope!” Philosophy \& Technology 24(1):69-82.

Ihde, Don. 2012. Experimental Phenomenology. Multistabilities. Albany, NY: State of University New York Press.

Kissmann, Ulrike T. 2014. Die Sozialität des Visuellen. Fundierung der hermeneutischen Videoanalyse und materiale Untersuchungen [The Sociality of the Visual. Foundation of Hermeneutic Video Analysis and Material Investigations]. Weilerswist: Velbrück.

Kissmann, Ulrike T. 2019. “What Makes Sensation of a Sentient Thing Possible: The Concept of Time in the Work of Maurice Merleau-Ponty." Pp. 21-38 in Discussing New Materiality, edited by U. T. Kissmann and J. van Loon. Wiesbaden: Springer.

Knoblauch, Hubert. 2000. “Workplace Studies und Video. Zur Entwicklung der visuellen Ethnographie von Technologie und
Arbeit [Workplace Studies and Video. On the Development of the Visual Ethnography of Technology and Work]." Pp. 159-174 in Arbeitskulturen im Umbruch. Zur Ethnographie von Arbeit und Organisation [Working Cultures in Transition. On the Ethnography of Work and Organization], edited by I. Götz and A. Wittel. Munich: Waxmann.

Knoblauch, Hubert and René Tuma. 2020. “Videography. An Interpretive Approach to Video-Recorded Micro-Social Interaction." Pp. 129-142 in The Sage Handbook of Visual Methods, edited by E. Margolis and L. Pauwels. Los Angeles: SAGE.

Knorr Cetina, Karin. 1997. "Sociality with Objects. Social Relations in Postsocial Knowledge Societies." Theory, Culture E Society 14(4):1-43.

Laurier, Eric et al. 2008. "Driving and 'Passengering': Notes on the Ordinary Organization of Car Travel." Mobilities 3(1):1-23.

Lindemann, Gesa. 1999. “Doppelte Kontingenz und reflexive Anthropologie [Double Contingency and Reflexive Anthropology]. Zeitschrift für Soziologie 28(3):165-181.

Lindemann, Gesa. 2009. “Gesellschaftliche Grenzregime und soziale Differenzierung [Societal Border Regimes and Social Differentiation]." Zeitschrift für Soziologie 38(2):94-112.

Lupton, Deborah. 2002. “Road Rage: Drivers' Understandings and Experiences." Journal of Sociology 38(2):275-290.

McLuhan, Marshall. 1994. Understanding Media. The Extensions of Man. Cambridge: MIT Press.

Nazif-Munoz, Jose Ignacio. 2013. “Departing from Risky Drivers? A Sociological Analysis of Passengers' Risk Factors." Annals of Advances in Automotive Medicine 57:357-360.

Schmidl, Alexander. 2017. “Verbreiterte Realität und Vertiefte Rahmen-Analyse [Augmented Reality and In-Depth Frame-Analysis]." Pp. 1-10 in Geschlossene Gesellschaften. Verhandlungen des 38. Kongresses der Deutschen Gesellschaft für Soziologie in Bamberg 2016 [Closed Societies. Negotiations of the $38^{\text {th }}$ Congress of the German Society for Sociology in Bamberg 2016], edited by S. Lessenich. Retrieved August 03, 2020 (http://publikationen. soziologie.de/index.php/kongressband_2016/article/view/423).

Suchman, Lucy A. 1985. Plans and Situated Actions. The Problem of Human-Machine Communication. Palo Alto: Xerox Corporation.

Verbeek, Peter-Paul. 2005. What Things Do. Philosophical Reflections on Technology, Agency, and Design. University Park, PA: The Pennsylvania State University Press. 
The Driving Lesson as a Socio-Technical Situation. A Case Study on the Interaction between Learner Driver, Driving Instructor, and the Motor Car

\section{Citation}

Schmidl, Alexander. 2021. “The Driving Lesson as a Socio-Technical Situation. A Case Study on the Interaction between Learner Driver, Driving Instructor, and the Motor Car." Qualitative Sociology Revieww 17(2):6-21. Retrieved Month, Year (http://www. qualitativesociologyreview.org/ENG/archive_eng.php). DOI: http://dx.doi.org/10.18778/1733-8077.17.2.01 